\title{
Relationship of Knowledge and Attitudes of Managerial Officers with their Solid Waste Management Practices in Sri Lanka
}

\author{
W.D.C.T. Gunasiri \\ University of Sri Jayewardenepura \\ G.D.V.R. Senadheera \\ University of Sri Jayewardenepura
}

\begin{abstract}
As in many developing countries, Solid Waste Management (SWM) is a key issue in Sri Lanka, and the quantity and the quality of the waste generated are directly influenced by the knowledge, attitudes and practices of people. Poor community participation is one of the main barriers for finding a sustainable solution for the said problem. The main objective of this study is to investigate the relationship of knowledge and attitudes with the waste management practices followed by managerial officers in Sri Lanka which is considered as a significant group of the society because of their education level and direct involvement of decision making at organizational and national level. Population was selected as students who studied Master of Business Administration (MBA) of University of Sri Jayewardenepura as they are supposed to be the future leaders of the country. Among them hundred students were randomly selected to the sample, representing managerial level officers in different sectors. Knowledge, attitudes and practices were taken as variables and they were measured using few dimensions. Data was mainly collected through selfadministered questionnaire. The version 22.0 SPSS package was used for data analysis. According to the findings, majority of MBA students possessed moderate level of knowledge and more than $75 \%$ of respondents had moderate
\end{abstract}

\section{Corresponding Author:}

W.D.C.T. Gunasiri, Faculty of Management Studies and Commerce, University of Sri Jayewardenepura, Sri Lanka

E-mail: chethikagunasiri@gmail.com 
level attitudes on solid waste related aspects. However, $15.9 \%$ of MBA students had poor attitudes on solid waste and especially on value of waste.

Regarding their practices, nearly $40 \%$ of respondents follow poor waste management practices and it reached more than 55\% in waste segregation and recycling behaviors. Knowledge on solid waste didn't show a significant relationship with their practices. However, a weak positive correlation was found between overall attitudes and waste management practices $(r=0.267)$ and a moderate positive correlation between attitudes on responsibility on public participation and practices $(r=0.539)$. Therefore, among MBA students, only the attitudes showed a significant positive impact towards SWM practices, not the knowledge. Hence, through building correct attitudes which need to be initiated from ground level can effectively contribute to implement sustainable waste management mechanism as attitudes of these future leaders are influential not in individual level but also in organizational and national level.

\section{Keywords}

Solid waste; Waste management practices; Knowledge; Attitudes; Managerial level officers

\section{Introduction}

Solid waste is a challenge faced by both developed and developing countries (Mbuligwe, 2002). However, solid waste management continues to be a major challenge that is faced by all urban areas in the world and this is a more prevalent issue in developing countries with rapidly growing cities and town developments (Jing et al., 2009 and Guerrero et al., 2013). Increasing population levels, rapid urbanization, booming economy and rise in community living standards which have significantly increased the speed of municipal solid waste generation in developing countries (Minghua et al., 2009).

Solid waste is the useless and unwanted products in the solid state arising from domestic, trade, commercial, agricultural, industrial, mining activities and from public services as well (Bhuiyan, 2010). Drastic changes occurring in human lifestyles, as a result of concentrated activities by the population, businesses, agriculture, industries, and institutions, in the recent past have caused substantial increase of solid waste generation and especially failing of implementing proper management has caused the waste as a major global issue. 
Waste management is an integrated system to manage the waste and this includes, waste reduction, composting, collection and transport, recycling, energy recovery, treatment and disposal (Moller \& Uhre,1996) and these management systems should be economically viable, socially acceptable and environmentally effective to become sustainable (McDougall et al., 2001).

The factors affecting the proper implementation of solid waste management systems fall into four categories; technical, environmental, socio-cultural, legal and institutional (Guerrero et al., 2013). The general concept is waste management is a sole responsibility of the government therefore, the public participation is largely neglected (Vidanaarachchi et al, 2006). But many past studies have proven that socio-cultural factors have high impact on effective solid waste management systems such as people's participation in decision making (Sharholy et al., 2008) and public awareness and community apathy in contributing for finding solutions (Moghadam et al., 2009).

Public attitude, knowledge and practices are the main factors influencing urban solid waste management in the developing world (Srivastava et al., 2015). Kofoworola (2007) says that individual or group awareness and attitudes towards waste generation and management are critical in the effort to respond to waste management challenges. The study conducted for undergraduate students at Philippines State University shows that knowledge and attitude of students on solid waste have a positive effect on practicing behaviors of solid waste management and many socio-demographic factors (Barloa et al., 2016). Study conducted in University of Rajasthan showed there is a significant association between knowledge with practices and knowledge with attitudes (Arora \& Agrawal, 2011). Further they revealed that, students who possessed good knowledge also have a good level of practices, and they were able to manage waste in a proper manner. As per a study conducted in Lahore city Pakistan, attitude and participation of local community towards solid waste management is the key component for the successful implementation of any waste alleviation program and industrial solid waste management (Haider et al, 2015).

Being a developing country, Sri Lanka still experiences unacceptable solid waste disposable practices and this is one of the biggest current environmental problems in the country. Illegal dumping is a common practice in Sri Lanka with approximately $20 \%$ residents dump their waste on road sides (Bandara, 2008) and according to Visvanathan (2006), 85\% of collected waste in Sri Lanka is subjected to open dumping. The seriousness of this issue was revealed 
with the tragedy of collapsing Meethotamulla garbage dump in year 2017 killing 19 people. Many studies have shown that public attitude, perception and knowledge on waste management are key factors for the success of integrated waste management mechanisms in the country (Bandara, 2008; Hikkaduwa et al., 2015). However, as identified, one of the main barriers for implementing sustainable solid waste management practices in Sri Lanka is low community participation.

Therefore, the research problem that was tried to address from the present was "what is the current level of knowledge, attitudes and practices of solid waste management of managerial officers in Sri Lanka and is there a relationship between their knowledge and attitudes with waste management practices?"

Managerial level officers were selected for the present study because of their education level and direct involvement of decision making at organizational and national level. Therefore, objectives of the study were; (a) to identify the level of knowledge and attitudes in solid waste management among managerial officers, (b) to identify waste management practices they apply and (c) to examine the relationships between knowledge and attitudes with their waste management practices. Since managerial officers are influential group of the country, it was expected that the findings of this study could contribute for designing and implementing appropriate effective solid waste management practices in Sri Lanka.

\section{Methodology}

\section{Research design}

Knowledge of solid waste management is significantly associated with the waste management practices (Arora \& Agrawal, 2011) and attitude and participation of people towards solid waste management is a key component for the successful implementation of waste alleviation programs (Haider et al., 2015 and Udompornin, 2015). Therefore, in present study, knowledge and attitudes and waste management practices of managerial officers in Sri Lanka were used as variables. Three dimensions were selected for each variable and indicators were chosen to measure each dimensions. Knowledge variable had three dimensions; knowledge on impacts of waste, knowledge on segregation and knowledge on sustainable management whereas attitude variable also had three dimensions; attitude on responsibility of waste management, attitudes on 
safe disposal and attitudes on value of waste. Moreover, waste management practices variable was measured with three dimensions; disposal, segregation and recycling.

Figure 1: Conceptual Framework

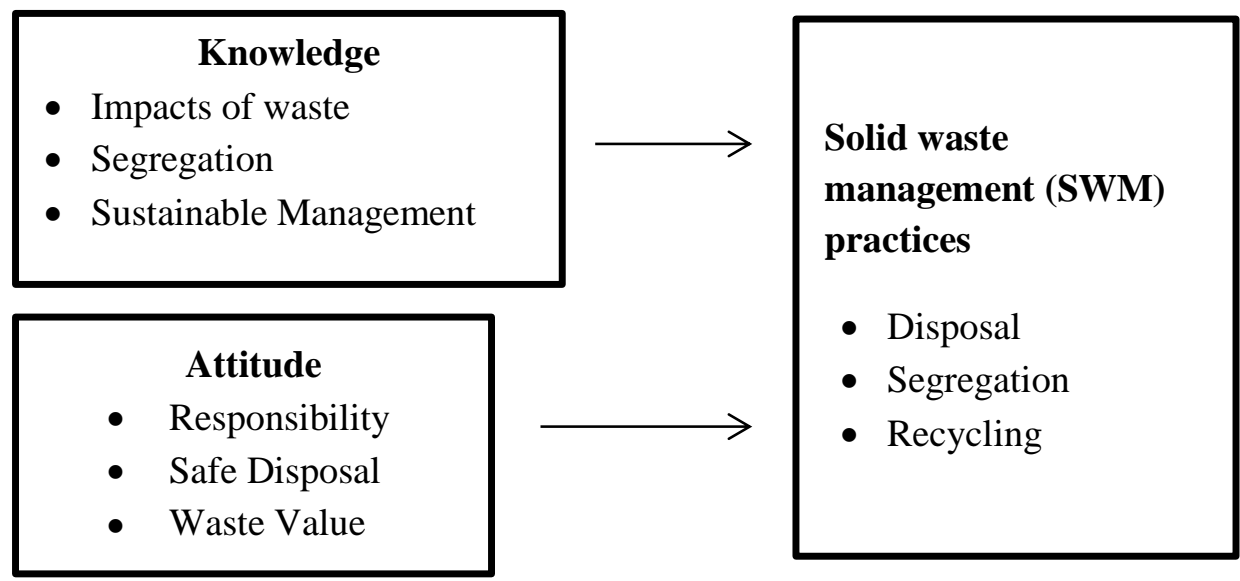

\section{Population}

The population was taken as MBA students, as they are all managerial level officers and represent a wider cross section of managers in the country due to many reasons such as, representing both private and government sectors, belonging to different disciplines as well as different managerial levels.

\section{Sampling method}

The sample was selected from the students following the MBA degree program at the University of Sri Jayewardenepura as it is one of the leading MBA programs in the country which covers a wide range of managers representing many organizations. Accordingly hundred students were selected randomly as the sample, representing managerial level officers in different sectors for the survey.

\section{Instrument used}

Self-administered questionnaire was used to gather information on demographic data of the sample, knowledge and attitudes on waste and current waste management practices they adopt. The questionnaire was pre-tested using 28 students to ensure feasibility, reliability and validity. 


\section{Data Analysis}

The Likert scale was used to measure the strength of each individual's knowledge, attitude and practices on waste management by assigning nominal values to items according to the scales. Four Likert scales of strongly agree (SA), agree (A), disagree (D), and strongly disagree (SD) were used to measure the knowledge and attitudes whereas Very Often (VO), Often (O), Not Often (NO) and Never (N) were used to measure waste management practices (Jatau, 2013). To determine the levels of knowledge, attitude and practice statistically, the scores for each dimension was partitioned. The mean value added to one standard deviation represented the upper limit while the mean value minus one standard deviation represented the lower limit. The mean values above the upper limit were considered as high, values below the lower limit were considered as low while values lying between the upper and lower limits were considered as moderate (Adeolu et al., 2014). Descriptive statistics; frequency percentages, mean and standard deviation were used to describe the studied variables. Pearson's Correlation test was used to assess the relationship between variables. Statistical analysis was carried out using SPSS 22.0 software.

\section{Results}

\section{Demographic characteristics of respondents}

The questionnaire was given to randomly selected hundred MBA students and eighty two questionnaires were received, therefore, the response rate was $82 \%$. The results analyzed show that respondents used for this study possess the following demographic characteristics; the total number of respondents is eighty two $(n=82)$ and the males are $53.7 \%$ and females are $46.3 \%$. Their age ranges are, $31.7 \%$ for age $20-30$ years, $50 \%$ for $31-40$ years and $15 \%$ for $41-50$ years. $73.2 \%$ respondents have postgraduate level qualifications and $25.6 \%$ and $1.2 \%$ have graduate and diploma level qualifications respectively. $68.8 \%$ respondents are working in the private sector, $14.6 \%$ in government or semi-government institutions, $14.6 \%$ are in international organizations and $2.4 \%$ are selfemployed.

\section{Statistical levels of Knowledge, Attitudes and Practices}

According to the Table 1, majority $(67.1 \%)$ have moderate level of knowledge on solid waste related aspects and $14.6 \%$ have good knowledge and $18.3 \%$ belongs to the poor knowledge category, revealing that the combined knowledge on waste related aspects of respondents is at average level. When 
considering each dimension measured related to knowledge on solid waste, for the knowledge on impacts of solid waste, $74.4 \%$ possess moderate knowledge, $11 \%$ have a good level of knowledge whereas, $14.6 \%$ belongs to low level (poor). In knowledge regarding waste segregation, $69.5 \%$ have a moderate level of knowledge and $11 \%$ and $19.5 \%$ have a good level and poor level respectively. In knowledge on solid waste management practices, majority (67.1\%) possesses moderate level, $18.3 \%$ are having poor knowledge and $14.6 \%$ respondents have good knowledge.

Table 1: Level of knowledge on waste (combined) and knowledge level on three different dimensions

Poor Moderate Good

$\begin{aligned} & \text { Level of combined } \\ & \text { knowledge on waste }\end{aligned}$
related aspects

Level of knowledge on three different dimensions

$\begin{array}{lccc}\begin{array}{l}\text { Knowledge on } \\ \text { impacts of waste }\end{array} & 12(14.6) & 61(74.4) & 9(11.0) \\ \begin{array}{l}\text { Knowledge on } \\ \text { waste segregation }\end{array} & 16(19.5) & 57(69.5) & 9(11.0) \\ \begin{array}{l}\text { Knowledge on } \\ \text { sustainable solid } \\ \text { waste management }\end{array} & 12(14.6) & 55(67.1) & 15(18.3)\end{array}$

* Values in parenthesis are percentages

The data in Table 2 shows, attitudes on waste aspects, $74.4 \%$ have moderate level attitudes, $12.2 \%$ have good attitudes whereas, $13.4 \%$ have poor attitudes. When considering level of attitudes respected to each dimension measured, responsibility for participation in waste management, $74.4 \%$ shows moderate level attitudes, 9.8\% are good and $15.9 \%$ have poor attitudes. The attitudes towards waste disposal practices, $57 \%$ have moderate level attitudes for good disposal practices, $13 \%$ are good attitudes and but $17 \%$ possess poor attitudes. 
For the attitudes for value of waste, majority (57.3\%) shows moderate level attitudes, $12.2 \%$ are good and $30.5 \%$ are poor.

Table 2: Level of attitudes on waste (combined) and attitude level on three different dimensions

Poor Moderate Good

\begin{tabular}{lllll}
\hline Level of & attitudes & $11(13.4) *$ & $61(74.4)$ & $10(12.2)$
\end{tabular}

(combined) on waste related aspects

Level of attitudes on three different dimensions

$\begin{array}{llll}\begin{array}{l}\text { Attitude on public } \\ \text { responsibility on solid }\end{array} & 13(15.9) & 61(74.4) & 8(9.8) \\ \text { waste management } & & & \\ \begin{array}{l}\text { Attitude on waste } \\ \text { disposal }\end{array} & 14(17.1) & 57(69.5) & 11(13.4) \\ \begin{array}{l}\text { Attitude on value of } \\ \text { waste }\end{array} & & & \\ \end{array}$

* Values in parenthesis are percentages

In the results of waste management practices (Table 3), in the combined results, half of the respondents $(50 \%)$ apply poor waste management practices and $35.4 \%$ and $14.6 \%$ have moderate and good practices respectively. When considering results of each dimension measured respected to waste management practices, for waste disposal, majority (79.3\%) have moderate level which means they are not practicing safe disposal techniques more often or bad disposal methods more often and only $4.9 \%$ apply good practices and $15.9 \%$ still uses bad practices. However, the practice of segregation and recycling are very poor among managerial level officers as $67.1 \%$ and $76.8 \%$ respondents never or not often separate wastes prior to disposing of or recycling waste respectively. When further analyzing the waste management practices (Table 4), $46.3 \%$ respondents are often or more often do open dumping and $43.6 \%$ never or not often do open dumping. Interestingly, $89 \%$ of respondents are still practicing burning of non-biodegradable material. However, in waste segregation, $50 \%$ separates waste often or very often and more than half $(57.4 \%)$ separates biodegradable waste from non-degradable waste. But also the other $50 \%$ do not or rarely practice waste segregation. However, recycling 
practice of managerial level officers are still at very poor lever, in which, only $84.4 \%$ never give or not often give recyclable waste to recycling centers and only $18.3 \%$ are practicing composting and also only $6.1 \%$ are willing to purchase recyclable goods or things produced by recycled materials.

Table 3: Level of waste management practices (combined) and practices on three different dimensions

Poor $\quad$ Moderate Good

\begin{tabular}{llll}
\hline Level of waste management & $41(50) *$ & $29(35.4)$ & $12(14.6)$
\end{tabular} practices (combined)

Level of waste management practices on three different dimensions

\begin{tabular}{lcccc}
$\begin{array}{l}\text { Waste } \\
\text { practices }\end{array}$ & disposal & $13(15.9)$ & $65(79.3)$ & $4(4.9)$ \\
$\begin{array}{l}\text { Waste } \\
\text { practices }\end{array}$ & segregation & $55(67.1)$ & $12(14.6)$ & $15(18.3)$ \\
$\begin{array}{l}\text { Waste } \\
\text { practices }\end{array}$ & recycling & $63(76.8)$ & $7(8.5)$ & $12(14.6)$ \\
\hline
\end{tabular}

*Values on parenthesis are percentage

Table 4: Waste management practices apply by respondents

\begin{tabular}{lllll}
\hline & Never & $\begin{array}{l}\text { Not } \\
\text { Often }\end{array}$ & Often & $\begin{array}{l}\text { Very } \\
\text { Often }\end{array}$ \\
\hline I do open dumping & 11 & 33 & 33 & $5(6.1)$ \\
& $(13.4)^{*}$ & $(40.2)$ & $(40.2)$ & \\
$\begin{array}{l}\text { I give my waste to the waste } \\
\text { collectors }\end{array}$ & $4(4.9)$ & 41 & 33 & $2(4.9)$ \\
$\begin{array}{l}\text { I burn non-degradable waste } \\
\text { (plastic, polythene etc) }\end{array}$ & $1(1.2)$ & $8(9.8)$ & 66 & $7(8.5)$ \\
$\begin{array}{l}\text { I separate waste as degradable } \\
\text { and non-degradable }\end{array}$ & $9(11.0)$ & 26 & $3(3.7)$ & $44(53.7)$ \\
$\begin{array}{l}\text { I separate e-waste and other } \\
\text { hazardous waste from general }\end{array}$ & & $(31.7)$ & & \\
\end{tabular}


waste

I practice waste segregation $17(20.7) \quad 24$

whenever I dispose of waste

I give recyclable material to $20(24.4) \quad 50(61) \quad 6(7.3) \quad 6(7.3)$ recycling centers

I use biodegradable waste to $43(52.4) \quad 24 \quad 11$

produce compost

I prefer to buy goods made from 27 (32.9) $\quad 50$

$2(2.4) \quad 3(3.7)$

recyclable and recycled material

*Values in parenthesis are percentages

\section{Relationship between knowledge and attitudes on waste management practices}

Pearson's Correlation Test was carried out to analyze the relationships between knowledge and attitudes with waste management practices. Analysis in Table 5 suggests, knowledge does not significantly correlate with waste management practices. Further, the dimensions of knowledge variable; knowledge on impacts of wastes, knowledge on waste segregation and knowledge on waste management also not significantly correlate with waste management practices. However a significant relationship is found between the attitudes and overall practices with a weak positive correlation $(\mathrm{r}=0.267)$. Also the relationship between attitude on public responsibility and practices also statistically significant which is averagely strongly positive $(\mathrm{r}=0.539)$. But attitude on waste disposal and value of waste are not significantly correlated with waste management practices. Hence it can be concluded that the attitudes of respondents on waste has a positive impact on their waste management practices especially attitude on their responsibility significantly influence on waste management practices.

Table 5: Correlation coefficients (r) between variables

Waste Management Practices

$\begin{array}{lll}\text { Sig. (2- } & \text { r } & \text { Relationship } \\ \text { tailed) } & & \end{array}$




\begin{tabular}{|c|c|c|c|}
\hline 1. Knowledge & .236 & 0.132 & $\begin{array}{l}\text { No significant } \\
\text { relationship }\end{array}$ \\
\hline $\begin{array}{l}\text { 1a. Impacts of } \\
\text { waste }\end{array}$ & .124 & 0.171 & $\begin{array}{l}\text { No significant } \\
\text { relationship }\end{array}$ \\
\hline $\begin{array}{ll}\begin{array}{ll}\text { lb. } \\
\text { segregation }\end{array} & \text { Waste }\end{array}$ & .541 & 0.068 & $\begin{array}{l}\text { No significant } \\
\text { relationship }\end{array}$ \\
\hline $\begin{array}{l}\text { 1c. Waste } \\
\text { management }\end{array}$ & .231 & 0.134 & $\begin{array}{l}\text { No significant } \\
\text { relationship }\end{array}$ \\
\hline 2.Attitude & .015 & $0.267 *$ & $\begin{array}{c}\text { Weak Positive } \\
\text { Correlation }\end{array}$ \\
\hline $\begin{array}{l}\text { 2a. Public } \\
\text { responsibility }\end{array}$ & .000 & $0.539 * *$ & $\begin{array}{l}\text { Moderate Positive } \\
\text { Correlation }\end{array}$ \\
\hline 2b. Waste disposal & .136 & 0.166 & $\begin{array}{l}\text { No significant } \\
\text { relationship }\end{array}$ \\
\hline 2c. Value of waste & .908 & 0.013 & $\begin{array}{l}\text { No significant } \\
\text { relationship }\end{array}$ \\
\hline
\end{tabular}

$*$ Correlation is significant at the 0.05 level (2-tailed). **. Correlation is significant at the 0.01 level (2-tailed)

\section{Discussion}

As per the findings of this study, the managerial level officers have a moderate level of knowledge towards solid waste management related aspects. Even though they are involved in different occupations, their environmental knowledge are at an acceptable level may be due to most of the respondents have tertiary level education. This is supported by the finding of Yadavannavar et al. (2010). However, when considering each dimension of knowledge measured from the respondents it was noticeable that one fifth of them have poor knowledge on waste segregation aspects though it has become a legal requirement of the country now. This was more prominent having a result of $67.1 \%$ respondents are practicing poor waste segregation practices. 
Also the study found that, the level of attitudes of the majority of managerial officers in Sri Lanka to waste management was at moderate level. This further proves the findings of Barloa et al. (2016); Ramos \& Pecajas (2016) and Ranu et al. (2016). Since managerial officers are educated (majority have tertiary education), responsible people as well as decision makers in society, it can be expected that their positive attitudes have been created through the education and employment status. However, having 25\% of respondents with poor attitudes for value of waste, it can be said that even though managerial officers are educated and responsible people in society there is a significant group who have poor attitudes on solid waste related aspects. However, Tatlonghari \& Jamiasm (2010) have shown earlier that considering waste as a resource which can be actually benefited for people is a positive factor in campaigns that involve in development of desirable attitudes on solid waste management.

Though these managerial level officers possess moderate level of knowledge on solid waste aspects, they showed poor practices which agree with Tikka et al. (2000), who has mentioned that according to some scholars, environmental knowledge does not lead to improve practice. Further, having significantly high number of respondents who have poor waste segregation practices revealing that even among educated people in society waste segregation is still not a common practice. This finding proved the results of Ehrampoush \& Moghadam (2005), where a majority (66\%) of medical science students in Yazd University in Iran did not practice solid waste segregation. According to Banga (2011), reasons for people to practice poor waste segregation can be; considering it as a time consuming activity, lack of a ready market for recyclable waste, not understanding the importance of waste separation and lack of space. These reasons may be applicable to the Sri Lankans as well because waste segregation is a still not a familiar practice for many people in our society and most of them see it as an extra burden and are also not very much aware about its importance.

Moreover, the recycling practices among the respondents were also significantly at poor level having $76.8 \%$ in the lowest category, revealing that still many Sri Lankans are not still familiar with recycling practices. This result was in line with the $25 \%$ of respondents who have poor attitudes on value of waste. It further disclosed that a considerable number of managerial officers who were sampled consider waste is just a dumping material which cannot be utilized to produce other value added products. This is one of the main reasons 
that solid waste has become a serious issue in Sri Lanka as the majority of solid wastes are still dumped without getting any secondary use. This is further in line supporting the findings of Bendak and Attili (2017) where only a small percentage of people in developing countries truly participate in recycling even though they are aware of the environmental degradation happening due to solid waste and how waste recycling can improve the quality of the environment and save resources. According to this past study, the reason for poor recycling practices in developing countries is lack of resources available to the public to encourage them for recycling. This can be a potential reason for Sri Lanka as well, as the level of practicing waste recycling is still at a very poor level among Sri Lankan people. Also as per the present study, managerial officers in Sri Lanka are still adopting wrong solid waste management practices such as open dumping which proves the findings of Adeolu et al. (2014), Chima et al. (2011) and Ramos \& Pecajas (2016). This shows that, even among the educated and responsible citizens, still there is a considerable group which uses wrong and unaccepted waste management practices. This may be due to the fact that they are not considering it as a wrong action or they are under estimating its results to the environment even they possess moderate level knowledge and attitudes on solid waste.

The findings of relationships between variables showed that there was no significant relationship between the overall knowledge or either it's three dimensions that were measured with the waste management practices. This reveals that the knowledge of managerial officers in Sri Lanka on solid waste does not affect their practices in solid waste management. This further implies that even though they have average knowledge on solid waste they don't use it when they engage in waste management practices in their day to day lives. This discloses that there is a gap between environmental knowledge and practices even among the highly educated and responsible people in Sri Lankan society.

However, the respondent's attitudes showed weakly positive significant relationship with their waste management practices. This relationship supports findings of previous studies (Barloa et al., 2016; Haider et al., 2015; Gusti, 2016). The majority of respondents had moderate level attitudes and half of them have moderate or good level of practices. Considering these results it can be said that when managerial level officers have more moderate level attitudes on solid waste they tend to practice well waste management techniques. This is reliable with the theoretical assumption in the Theory of Planned Behavior, that 
the attitude is a determinant element in the intention (Fishbein \& Ajzen, 1975). Attitude plays a significant role in environmental actions of people.

Through this study it was able to identify levels of knowledge, attitudes and waste management practices as well as attitudes as one of the factors influencing for solid waste management practices of an important segment of Lankan society (managerial officers). Also it was found that that knowledge had no impact on solid waste management practices among managerial officers in the population considered. Hence results of the study are important to identity suitable solutions for the current solid waste management issue to a certain extent. According to the results of this study, out of knowledge and attitudes, only attitude showed a significant relationship to the solid waste management practices of managerial officers. Therefore, creating positive attitudes on solid waste among this important group is vital. This can be achieved through proper awareness campaigns especially on the importance of proper solid waste management, to treat waste as a resource, to which value additions can be given, the importance of waste segregation and waste recycling etc. Since managerial level officers are decision makers and responsible people in the society and leaders for many people, creating correct attitudes among them is more influential to a wider range of society. Correct practices directly influence achieving proper solid waste management practices in the country.

\section{Conclusion}

Solid waste management is one of the major environmental and social issues in Sri Lanka, and one of the main barriers for implementing sustainable solid waste management practices is low community participation. Hence this study was carried out to identify the relationship of knowledge and attitudes towards the solid waste management practices among managerial officers in Sri Lanka, one of the significant social groups in the country, due to their responsibility and influence on people and their direct involvement in decision and policy making. Majority of managerial officers possess a moderate level of knowledge and attitudes on solid waste aspects, but half of them are practicing poor waste management practices and the rest are practicing moderate or good practices. Significant percentage of managerial officers in Sri Lanka don't have good attitudes on the value of waste and interestingly, still a substantial number of them still practice poor waste management practices such as open dumping and open burning. Waste segregation and recycling behavior among the managerial officers are also at very poor level. Knowledge on solid waste of managerial 
officers do not disclose a significant relationship with their waste management practices, but their attitudes on waste show a significant relationship with the practices and which is a positive correlation. The results of the study are important to identity suitable solutions for the current solid waste management issues to a certain extent. Implementing proper awareness programs to establish positive attitudes especially on waste segregation, value of waste and recycling among managerial officers, organizing large scale awareness campaigns and introducing innovative processes and technologies to make proper waste management practices familiar to the public are some managerial implications that can be practiced to implement sustainable waste management mechanism in the country. Further, in order to recognize the problem in more deeper sense, future studies need to be carried out to identify other potential factors especially social and economic factors of managerial level officers which can be influenced to solid waste management practices as well as to extend this study to other social groups as well.

\section{References}

Adeolu, A.T., Enesi, D.O., \& Adeolu, M.O. (2014), “Assessment of Secondary School Students' Knowledge, Attitude and Practice towards Waste Management in Ibadan, Oyo State, Nigeria", Journal of Research in Environmental Science and Toxicology, Vol. 3, No. 5, pp. 66-73.

Arora, L., \& Agarwal , S. (2011). "Knowledge, Attitude and Practices regarding Waste Management in Selected Hostel Students of University of Rajasthan, Jaipur', International Journal of Chemical, Environmental and Pharmaceutical Research, Vol. 2, No. 1, pp. 40-43.

Bandara, N. J. (2008), "Municipal Solid Waste Management - The Sri Lankan Case", Conference on Developments in Forestry and Environmental Management in Sri Lanka. Kaluthara" Sri Lanka.

Banga, M. (2011), "Household Knowledge, Attitudes and Practices in Solid Waste Segregation and Recycling: The Case of Urban Kampala", Zambia Social Science Journal, Vol. 2, No. 1, pp. 27-39.

Barloa, E. P., Lapie, L., \& de la Cruz, C. (2016), "Knowledge, Attitudes, and Practices on Solid Waste Management among Undergraduate Students in a 
Philippine State University', Journal of Environment and Earth Science, Vol. 6, No. 6, pp. 146-153.

Bendak, S. \& Attili , A. B. (2017), "Consumers Attitude and Behavior Towards Domestic Waste Recycling in Developing Countries: A Case", Advances in Recycling \& Waste, Vol. 2, No. 2, pp. 124.

Bhuiyan, S. (2010), "A crisis in governance: Urban solid waste management in Bangladesh", Habitat International, Vol. 34, No. 1, pp. 125-133.

Chima, G. N., Ezekwe, I. C., \& Digha, N. O. (2011), “An assessment of medical waste management in health institutions in Yenagoa, South-South, Nigeria", World Review of Science, Technology and Sustainable Development, Vol. 8, No. 2/3/4, pp. 224-233.

Ehrampoush, M., \& Moghadam, M. (2005), "Survey of knowledge, attitude and practice of Yazd University of Medical Sciences students about solid wastes disposal and recycling', Iranian Journal of Environmental Health Science and Engineering, Vol. 2, No. 2, pp. 26-30.

Fishbein, M., \& Ajzen, I. (1975). Belief, Attitude, Intention, and Behavior: An Introduction to Theory and Research. http://people.umass.edu/aizen/f\&a1975.html. 2017.06.12

Guerrero, L. A., Maas, G., \& Hogland, W. (2013), "Solid waste management challenges for cities in developing countries", Waste Management, Vol. 33, pp. 220-232.

Gusti, A. (2016), "The Relationship of Knowledge, Attitudes, and Behavioral Intentions of Sustainable Waste Management on Primary School Students in City of Padang, Indonesia", International Journal of Applied Environmental Sciences, Vol. 2, No. 5, pp. 1323-1332.

Haider, A., Amber, A., Ammara, S., Mahrukh, K., \& Aisha , B. (2015), "Knowledge, Perception and Attitude of common People towards Solid Waste Management-A case study of Lahore, Pakistan", International Research Journal of Environment Sciences, Vol. 4, No. 3, pp. 100-107.

Hikkaduwa, H.N., Gunawardana, K., Halwatura, R., \& Youn, H. (2015), "Sustainable Approaches to the Municipal Solid Waste Management in Sri 
Lanka", 6th International Conference on Structural Engineering and Construction Management 2015. Kandy, Sri Lanka.

Jatau, A. A. (2013), "Knowledge, Attitudes and Practices Associated with Waste Management in Jos South Metropolis, Plateau State", Mediterranean Journal of Social Sciences, Vol. 4, No. 5, pp. 119-127.

Jing, S., Huang, G. H., Xi, B. D., Li, Y. P., Qin, X. S., \& Huo, S. I. (2009), “A hybrid inexact optimization approach for solid waste management in the city of Foshan, China", Journal of Environment Manage, Vol. 91, No. 2, pp. 389-402.

Kofoworola, O. (2007), "Recovery and recycling practices in municipal solid waste management in Lagos, Nigeria", Waste Management, Vol, 27, No. 9, pp. 1139-1143.

Mbuligwe, S.E. (2002), "Institutional solid waste management practices in developing countries: A case study of three academic institutions in Tanzania”, Resource Conservation and Recycling, Vol. 35, No. 3, pp.136141.

McDougall, F. R., White, P., Franke, M., \& Hindle, P. (2001), Integrated Solid Waste Management:a Life Cycle Inventory, Second edition published by Blackwell Science.

Minghua, Z., Xiumin, F., Rovetta, A., Qichang, H., Vicentini, F., Bingkai, L., et al. (2009), "Municipal solid waste management in Pudong New Area, China", Waste Management, Vol. 29, No. 3, pp. 1227-1233.

Moghadam, M. R. A., Mokhtarani, N., \& Mokhtarani, B. (2009), "Municipal solid waste management in Rasht City, Iran", Waste Management, Vol. 29, No. 1, pp. 485-489.

Moller, J., \& Uhre, L. (1996), International Directory of Solid Waste Management, James and James Science Publishers Limited, London.

Ramos, J. N., \& Pecajas, E. (2016), "Knowledge, Attitudes And Practices In Solid Waste Management Among The Secondary Schools In The Division Of Leyte", International Journal of Engineering Sciences \& Research Technology, Vol. 5, No. 7, pp. 1452-1463. 
Ranu, R., Santosh, K., \& Manju, L. (2016), "Knowledge, Attitude and Practice Regarding Biomedical Waste Management amongst Health Care Personnel in a Medical College Hospital in Trivandrum", National Journal of Community Medicine, Vol. 7, No. 6, pp. 457-460.

Sharholy, M., Ahmad, K., Vaishya , R. C., \& Gupta , R. D. (2007), “Municipal solid waste characteristics and management in Allahabad, India", Journal of Waste Management, Vol. 27, No. 4, pp. 490-496.

Srivastava, V. S. A. (2015), "Urban solid waste management in the developing world with emphasis on India: challenges and opportunities", Reviews in Environmental Science and Bio/Technology, Vol. 14, No. 2, pp. 317-337.

Tatlonghari, R. V., \& Jamias, S. (2010), "Village-Level Knowledge, Attitudes and Practices on Solid Waste Management in Sta. Rosa City, Laguna, Philippines", Journal of Environmental Science and Management, Vol. 13, No. 1, pp. 35-51.

Tikka , P.M., Kuitunen , M., \& Tyns , S. M. (2000), "Effects of educational background on students' attitudes, activity levels and knowledge concerning the environment", Journal of Environmental Education, Vol. 52, No. 1, pp. 31-48.

Udomporn, T. (2015), “Resident's Knowledge, Attitude And Practice Towards Solid Waste Management In Joho Sub-District Administrative Organization, Mueang District, Nakhon Ratchasima, Thailand", International Journal of Technical Research and Applications, Vol. 24, pp. 13-16.

Vidanaarachchi, K.C., Yuen, S. T., \& Pilapitiya, S. (2006), "Municipal solid waste management in the Southern Province of Sri Lanka: Problems, issues and challenges", Waste Management, Vol. 26, No. 8, pp. 920-930.

Visvanathan, C. (2006), "Domestic solid waste management in South Asia', 3 R South Asia Expert Workshop. Kathmandu, Nepal.

Yadavannavar, M., Berad, B. A., Aditya, S., \& Jagirdar, P. B. (2010), “A Study of Knowledge, Attitude, and Practices in a Tertiary Health Care Institution in Bijapur", Indian Journal of Community Medicine, Vol. 35, No. 1, pp. 170-171. 